\title{
Zimbabwe Language Policy: Continuity or Radical Change?
}

\author{
Lovemore Sibanda \\ University of North Texas \\ lkgsibanda@hotmail.com
}

\begin{abstract}
This article evaluates the implementation of the new language policy introduced by the Zimbabwean government after independence from Britain in 1980. The study deploys decoloniality as the theoretical frame to examine whether the language policy of Zimbabwe is a radical departure from the colonial language policy. To determine the nature and character of the current language policy and practices I used coloniality of power, coloniality of knowledge, and coloniality of being as analytical lenses and utilized prior qualitative research studies on colonial and post-independence language policy and practices to support my analysis. I argue that despite the claim by the Zimbabwe government that it is a revolutionary government that would completely overhaul all colonial structures, institutions, and policies, the implementation of the language policy is a continuity, rather than transformational. Colonial language policy fundamentals are intact and present in the current language policy and practices. English is still the dominant language of instruction. Indigenous languages are considered inferior and on the verge of extinction. The policy failed where it matters most - engendering indigenous ways of thinking, knowing, seeing, doing and responding to the world to reclaim the African identity and consciousness. The language policy dismally fails to vigorously confront the "coloniality of power, of knowledge and of being". I recommend that the language policy must be grounded in robust research, and developed through a broad-based consultative process with specific implementation strategies and commitment by government and non-governmental agencies for funding its implementation.
\end{abstract}

\section{Introduction}

The colonization of Africa by European countries during the late 19th century led to the imposition of foreign languages. Colonial governments in Africa deliberately and systematically neglected indigenous languages as they enforced linguistic hegemony (Shizha, 2013). Zimbabwe was no exception. It is against this background that after attaining independence and sovereignty in 1980 the Zimbabwean government pursued an agenda for linguistic decolonization (Government of Zimbabwe, 1982). It was clear to the Zimbabwean people that political independence was meaningless unless it was accompanied by social-cultural and economic independence. The expectation in 1980 was that as a revolutionary party the ZANU PF (Zimbabwe African National Union-Patriotic Front) which had espoused a radical socialist ideology during the armed revolution and vowed to fundamentally transform all colonial policies, structures, and institutions, would develop and implement a language policy that was a radical departure from the colonial one (Government of Zimbabwe, 1982). Arguably, to expect that the ZANU PF government would thrust indigenous languages at the apex of the language pyramid was misplaced given the party's preference of using English in its official

Journal of Contemporary Issues in Education, 2019, 14(2), pp. 2-15. 
pronouncements and propaganda during the liberation war (Makoni, Dube, \& Mashiri, 2006). Both within and outside educational circles, a heated and furious debate is raging in Zimbabwe whether the postcolonial language policy in education represents a continuity of the colonial language policy or a radical change. This debate is relevant and timely in light of many Zimbabweans' desire and wish to liberate themselves in all sectors and spheres and from the limitations of Eurocentric thinking and perceptions (Makuvaza, 2008; Mavhunga, 2006). Zimbabwe's language policy after independence from Britain in 1980 is viewed by many Zimbabweans as cosmetic and superficial-failing to scratch where it itches. The majority of Zimbabweans desire language policy in education that elevates the status of indigenous languages to the level of English to raise the level of African consciousness and pride (Kadenge \& Nkomo, 2011). Most of the policymakers, politicians, administrators, and teachers in Zimbabwe were educated during the colonial era, "lack practical links [with] the mass of the people" and act cowardly at "decisive moments" in the history of the Zimbabwean polity, creating an "empty, crude and fragile" national consciousness, characterized by ethnic hatred and conflict, self-contempt, suspicion and cultural denigration (Fanon, 1952, p. 97). The postcolonial ruling elites schooled in colonial schools, run the risk of behaving as their colonial masters and are only black in skin but wearing white masks (Fanon, 1952). As Shizha (2013) accurately observes, African leaders and policymakers "internalized western philosophical and ideological tenets" via colonial education and this greatly impacts their "educational planning and policies" (p. 7).

Informed and guided by the theory of decoloniality, the main purpose of this paper is to critically analyze the post-independence Zimbabwe language policy and practices in education to determine whether the language policy radically changed or represents a continuity of the colonial era. To determine the nature and character of the current language policy and practices I used coloniality of power, coloniality of knowledge, and coloniality of being as analytical lenses and utilized prior qualitative research studies on colonial and post-independence language policy and practices to support my analysis. Few studies, which utilize theoretical frames, (particularly decoloniality), have been carried out to subject the Zimbabwe language policy to rigorous criticism. The paper is divided into four sections. The first section presents the theoretical framework that informs and guides the study. The second section offers a brief overview of the colonial and post-independence language policies. The third section critically discusses the postcolonial language policy and practices to determine continuity or radical change. The fourth provides the conclusion and the way forward.

\section{Theoretical Framework}

This article draws on the decoloniality theory to evaluate Zimbabwe's language policy and practices in education after independence in 1980. Decoloniality as "resistance, thought, and action" is cognizant of the shortcomings of African governments to free themselves from EuroNorth American world culture and European languages after the demise of colonial rule and the attainment of independence (Ndlovu-Gatsheni, 2015, p. 488). As an epistemological and political movement, it deconstructs and challenges the global ethnoracial hierarchy (Quijano, 2000) and the placing and universality of Eurocentric thoughts at the apex of history and culture and seeks to shift the "geopolitics of knowledge" (Mignolo, 2011). Space is created for marginalized

Journal of Contemporary Issues in Education, 2019, 14(2), pp. 2-15.

doi: 10.20355/jcie29377 ISSN 1718-4770

(c) Author(s), Creative Commons Attribution 4.0 (CC BY 4.0) licence

http://ejournals.library.ualberta.ca/index.php/JCIE 
peoples, as well as the reconstruction of knowledge as the experiences, identities, and languages of the indigenous peoples "becomes the starting point for transformation at the level of epistemology itself, [and] of the theory of practice of education" (De Lissovoy, 2014, p. 111).

The decoloniality lens provides the tools to destroy the master house and build something new. Its three key tenets or matrices of analysis are coloniality of power; coloniality of knowledge; and coloniality of being. Coloniality of power analyzes the "modern global cartography of power and how the modern world works" (Ndlovu-Gatsheni, 2015, p. 490). The concept of coloniality of power helps to understand how the world evolved and divided itself into two camps - those in control of global power structures and those who are controlled (outside the global power structures) — victims of slavery, imperialism, colonialism, and apartheid (Mignolo, 2011).

Coloniality of knowledge recognizes that Africa is still burdened with irrelevant knowledge and foreign languages after the calculated and systematic neglect and eradication of endogenous and indigenous knowledge and languages during the colonial era (Shizha, 2013; Shizha \& Abdi, 2014). Mignolo (2012) is on point to contend that coloniality of knowledge makes us understand how and why western intellectual practices translate, re-write other cultures and their knowledge and self-perception. This process pushed indigenous knowledge and languages to the margins, characterizing them as barbaric and backward (Ndlovu-Gatsheni, 2015).

Coloniality of being raises questions of subjectivity, self-pride, and self-assertion of Africans and resists the objectification and dehumanization of Africans (Ndlovu-Gatsheni, 2015). The identity and self-confidence of the Africans was (and still is) savagely assaulted, creating an inferiority complex and self-denigration. Coloniality of being interrogates how African humanity and languages are still being questioned, belittled, and undervalued. Coloniality of being acknowledges that the globalization agenda is driven by coloniality (Ndlovu-Gatsheni, 2015), and is maintained in "the self-image of peoples, in aspiration of self and many other aspects of ...modern experiences" (Maldonado-Torres, 2007, p. 243). In education, coloniality manifests itself in the intent and outcome of language policy, among many other issues. In the context of this study, decoloniality as the theoretical lens is employed and deployed to subject Zimbabwe language policy to a rigorous criticism using the three matrices of analysis. Arguably, very few prior studies used decoloniality as a theoretical frame to unpack the deficiencies of Zimbabwe's language policy.

\section{Background}

Zimbabwe had four colonial governments between 1890-1979: the BSAC (British South African Company) (1890-1922); White settler self-government (1923-1952); the Federation of Rhodesia and Nyasaland (1953-1963); and Rhodesian Front government (1965-1979), which had slightly different language policies (Nhongo, 2013; Nkomo, 2008; Thondlana, 2002). The language policies of these colonial governments were contingent upon the politics and economics of the day. English was the dominant official language and had a higher status than the indigenous languages (Makoni et al., 2006). The various colonial governments (1890-1979) imposed English as the language of instruction, commerce, and administration, "Europeanized" African languages (Makoni et al., 2006) and forbade the use of indigenous languages (Wa Thiong'o, Journal of Contemporary Issues in Education, 2019, 14(2), pp. 2-15. doi: 10.20355/jcie29377 ISSN 1718-4770 
1994) by students at school when talking to each other. Of the three colonial governments in Zimbabwe, it was the BSAC that encouraged white colonial officials to learn the indigenous languages for administrative purposes. On the other hand, the Rhodesian government developed a language policy that undervalued and underdeveloped indigenous languages and vigorously promoted the supremacy and dominance of English. The use of indigenous languages as media of instruction in grades one to three was discontinued, and English became the only medium of instruction from grade one (Mumpande, 2006). Indigenous languages were taught in English. Students were required to translate passages in indigenous languages to English. The colonizers wanted the use of European languages to define the mental universe, culture and being of the colonized (Fanon, 1952).

Colonial language policies and practices were characterized by "white linguistic supremacy" (Shizha, 2012) and western modernity was the main objective. Authors such as Sukumane (2000), Shizha and Abdi (2014), and Shizha (2013) correctly observe that indigenous languages were considered unscientific and obstacles to modernization. Colonial language policy through the dominance and hegemony of English created and sustained socio-economic disparities and created and ensured a racial hierarchy (Quijano, 2000; Sukumane, 2000). In the classroom, the use of a foreign language as a mode of instruction silenced indigenous voices as it "killed" student-teacher and student-student interactions (Shizha, 2012). The philosophy which drove colonial language policy is captured very well by Lugard (1922), the most eminent British colonial administrator:

As Roman imperialism laid the foundation of the modern civilization and led the wild barbarians of these islands along the path of progress, so in Africa today we are repaying the debt, and bringing to the dark places of the earth, the abode of barbarism and cruelty, the torch of culture and progress, while ministering to the material needs of our civilization.... We hold these countries because it is the genius of our race to colonize, to trade and to govern. (p. 618)

The English language and culture were to be the lynchpins of this "civilizing" project. To "civilize" and modernize the Africans English as a language and medium of instruction was to play a significant and critical role. This state of affairs was (and is) unacceptable after the demise of colonialism. Given that we transmit and receive our culture through language (Wa Thiong'o, 1994; Shizha, 2012), express ourselves through language, and language defines us as common members of a community, the systematic wiping out of indigenous languages and culture was an intentional attack on indigenous ways of thinking, knowing and being.

Seven years after independence, the Zimbabwe government passed the Education Act of 1987 to address the dominance and hegemony of English in particular and the transformation of the colonial language policy in general. The Education Act of 1987 enunciated the following provisions for language policy:

1. The three main languages of Zimbabwe, namely Shona, Ndebele, and English shall be taught in all primary schools from the first grade as follows: a. Shona and English in all areas where the mother tongue of the majority or the residences is Shona, or b. Ndebele

Journal of Contemporary Issues in Education, 2019, 14(2), pp. 2-15. 
and English in all areas where the mother tongue of the majority or the residence is Ndebele. 2. Prior to the fourth grade, either Shona or Ndebele may be used as the medium of instruction depending upon which language is more commonly spoken and better understood by pupils. 3. From the fourth grade, English shall be the medium of instruction provided that Shona or Ndebele shall be taught as subjects on equal time allocation as the English language. 4. In areas where minority language exists, the Minister may authorize the teaching of such languages in primary schools. (Government of Zimbabwe, 1987)

Shizha (2012) observes that although the 1987 Education Act was revised in 1990 it re-enforced the dominance and hegemony of English and strengthened the earlier transitional model aimed at a single target language (English) at the end of the school pipeline. Researchers, policy analysts, and educationists posit that the 1987 Act with regards to language policy and practices is not put into practice by teachers. Teachers, parents, and educational leaders prefer the use of English as medium of instruction from grade one as speaking English is equated to higher social and economic power and status (Nhongo, 2013, Thondhlana, 2000). Supporters of English as the sole medium of instruction contend that English is a global language and crucial for Zimbabwe's participation in the global economy (Nhongo, 2013). More importantly, English is considered a unifying force that builds national consciousness and identity and ensures communication between diverse linguistic groups (Nhongo, 2013; Muchenje, Goronga, \& Bondai, 2013). Native languages in comparison to English are considered of no value because they do "not render a person employable" (Ndamba, 2008). The provisions of the 1987 Act are ignored or implemented half-heartedly (Mufanechiya \& Mufanechiya, 2010). At the school level teachers implement the policy differently. Some teachers use English as a medium of instruction from grade one and others from grade three (as per policy) but half-heartedly (Mufanechiya \& Mufanechiya, 2010). Not all minority indigenous languages are used as medium of instruction (Muchenje et al., 2013). The confusion in the implementation of the language policy may be explained by the fact that teachers as key stakeholders were not consulted in the development of the language policy (Ndlovu, 2008; Mkandla, 2000). Many observers, researchers, and analysts posit that the government lacks the will and capacity to change the colonial language policy (Mnkandla, 2000; Nhongo, 2013). The government is accused of failing to mobilize financial, human and material resources to teach students in their indigenous languages beyond grade three (Mufanechiya \& Mufanechiya, 2010; Thondhlana, 2000). Further revision of the Education Act in 2006 allowed instruction in minor indigenous languages like Tonga and Kalanga. It also permitted the teaching of Shona, Ndebele, and English up to form 2 with the same instructional time in all districts in Zimbabwe. These changes are merely on paper and not in practice. It is worrisome and disturbing that Zimbabwe does not have a comprehensive and written single language policy document. Language policy is implied or inferred in scattered documents like the Education Act, the Cultural Policy of Zimbabwe, the Report of the Survey of the Teaching and Learning of Minority Languages in Zimbabwe, the Position Paper on Zimbabwe's Language Policy, the National Language Policy Advisory Panel Report, and the Nziramasanga Commission Report on Education and Training in Zimbabwe (Nhongo, 2013; Kadenge \& Nkomo, 2011; Nkomo, 2008; Ndhlovu, 2008). Undoubtedly, the Zimbabwe language policy raises a lot of questions that beg for answers. Is the Zimbabwe language policy a remarkable departure from the colonial language policy? Does the language policy fundamentally transform Journal of Contemporary Issues in Education, 2019, 14(2), pp. 2-15. doi: 10.20355/jcie29377 ISSN 1718-4770 
the language pyramid and landscape necessary to undo the consequences and effects of the colonial language policy? This will be discussed in the next section, using the framework of coloniality of power, coloniality of knowledge, and coloniality of being as analytical lenses.

\section{Continuity or Radical Change?}

Educationists, researchers, observers, and policy analysts are alarmed and disappointed by continuities rather than a transformation in the language policy introduced after independence (Nhongo, 2013; Nkomo, 2008; Shizha 2012; Thondhlana, 2000). They see similarities, not differences in the colonial and post-independence language policies, and posit that in developing its postcolonial language policy, the Zimbabwean government is following the colonial trajectory and arguments for its language policy. I argue that the Zimbabwean language policy perpetuates and reinforces the intent, purpose, and agenda of the colonial language policy and practices.

\section{Coloniality of Power: Language as Power}

As in colonial Zimbabwe, English in post-independent Zimbabwe is the preferred language of instruction in schools by teachers and parents (Makoni et al., 2006; Nhongo, 2013; Shizha, 2012; Thondhlana, 2008). According to Sukumane (2000), parents in the so-called developing countries prefer foreign languages as media of instruction. The Zimbabwe Languages Association described the Education Act of 1987, which is the linchpin of Zimbabwe language policy, as "characteristically colonial because it promotes English at the expense of developing indigenous languages" (Government of Zimbabwe, 1999, p. 161). Nkomo (2008) asserts that the Zimbabwean government has made English "not optional but compulsory" (p. 355) as the language of instruction in schools. Although Ndebele and Shona have been accorded the status of national languages, this status is only ceremonial and is used for "veiled political purposes of tribal balancing" (Ndlovu, 2008, p. 62). Nhongo (2013) claims that the situation with the other more than ten indigenous languages is worse off as they are overshadowed by the English language and preyed upon by dominant indigenous languages (Shona and Ndebele) to the extent that they are at the risk of extinction (Nhongo, 2013). It is evident that Zimbabwe has a language pyramid with English at the apex of this pyramid. Sadly, and most, unfortunately, indigenous languages are at the bottom of this pyramid.

As language and power are inseparable (Wa Thiong'o, 1994), the Zimbabwe language policy fits into the global cartography of power and bifurcation and does not in any way threaten or destabilize it. The Zimbabwe language policy maintains and sustains the global cartography of power and its bifurcation into those in control of global power structures (and beneficiaries of modernity) and those who are not, and must be controlled to their benefit. Noticeably and notably, the language pyramid with English at the apex of this pyramid mirrors the racially hierarchized organization of the world (Quijano, 2000). Sukumane (2000) accurately asserts that language plays a critical role in creating and sustaining socio-economic disparities and differences. Sukumane succinctly describes how language is used to maintain and sustain global cartography of power and how the modern world works":

Journal of Contemporary Issues in Education, 2019, 14(2), pp. 2-15. 
The dominance of English, especially as the language of modern technology, contributes to the unequal relations between 'developed' and 'developing' countries, because access to technological information depends upon institutional structures and relationships. To gain that access, new nations must develop the necessary linking institutions to serve as conveyors of the information that comes with ties to those who control it. (p. 201)

To this end, the dominance and hegemony of English as the medium of instruction continues unabated. English continues to be the language of power, status and economic success (Shizha, 2013; Shizha, 2012; Thondhlana, 2000) because it is considered an intervention to modernization and access to technology (Sukumane, 2000). Maldonado-Valentin (2016) argues that the selection of a particular language as the medium of instruction "grants economic advantages, power, and social mobility to those who are represented by the language of choice" (p. 5). English, French, and Portuguese are considered languages of power and of the powerful because they are deemed "scientific", and indigenous languages unscientific (Shizha, 2010). As was the case in colonial Zimbabwe, English as the medium of instruction continues to determine access to political and economic opportunities (Ndamba, 2008). English is still the language of the powerful and influential people in society. Indigenous people who are not competent in the language are left out of the corridors of power and influence (Bourdieu, 1991) - deprived of cultural and social capital in the post-independence context. Therefore, the Zimbabwe language policy inherently fails to contend with the fact that language is more than a means of communication, but is directly or indirectly linked to how the world is constituted and configured. Seemingly, the language policy buttresses and consolidates the bifurcation of the world and modern power structures.

\section{Coloniality of Knowledge: Production, Transmission, and Reception of Knowledge} Arguably, the Zimbabwe post-independence language policy dismally fails to use indigenous languages to vigorously confront and displace reified colonial knowledge perpetuated by the dominance and hegemony of English as the medium of instruction. The current language policy does not acknowledge that language and knowledge are intricately connected (Wa Thiong'o, 1994) and that language is much more than merely a means of communication (Shizha, 2012; Wa Thiong'o, 1994). Indigenous languages and practices are not leveraged for knowledge generation and dissemination, particularly in science (Shizha, 2012), to ensure and enhance cultural reclamation, liberation, and redemption after decades of colonialism and imperialism. According to Shizha (2012) languages of instruction are critical to the advancement of knowledge, skills, cognitive development and the production and transmission of knowledge ( $\mathrm{p}$. 877-878). Shizha further observes that language is important for transmitting and receiving cultural knowledge. In view of these observations, the following questions may be asked. Whose cultural knowledge are students transmitting and receiving when their medium of instruction is English? Most importantly, whose knowledge is being advanced and produced? These are questions the Zimbabwe language policy and practices do not vigorously and urgently address. Through the use of English as a medium of instruction, students transmit and receive a foreign culture and knowledge. As they think and acquire knowledge in a foreign language they may find it difficult to relate and connect to their immediate environment and cosmology.

Consequently, students also produce and advance knowledge which is not their own, as they are Journal of Contemporary Issues in Education, 2019, 14(2), pp. 2-15. doi: 10.20355/jcie29377 ISSN 1718-4770 
forced to know and think in ways that are foreign to them. To this end their discourse in class is constrained (Shizha, 2013; Shizha, 2012). Shizha's findings (2012) are instructive and speak to the interconnectedness of language and knowledge:

In everyday classroom instruction, teachers are threatening and unfriendly to students who are not proficient in the English language forcing students to withdraw from participating in class discussions. Instead of promoting dialogue, the English language frustrates and "kills" classroom interactions. (p. 880)

In the absence of dialogue in the classroom, teaching and learning become a monologue with the teacher as a fountain of knowledge, instead of a facilitator (Freire, 1972). As Shizha (2012) contends, the language policy silences indigenous voices. Students, therefore, do not produce any knowledge in schools, but uncritically regurgitate what they learn. Shizha further poignantly asserts that "it is in language that knowledge is transmitted, interpreted and configured" (p. 879). As a student in colonial Zimbabwe, I can testify that the use of English as a medium of instruction stifles creativity, thinking, and valuing of indigenous knowledge. Therefore, the lack of knowledge generation in classrooms made possible by the use of English as the medium of instruction may impress upon the students the supremacy of western epistemology. It perpetuates the belief that western knowledge, not indigenous knowledge, is valuable.

The language policy dismally does not utilize indigenous languages as a medium of instruction, a resource for learning, cognition and conceptual development (Brock-Utne, 2005) and as a "link between home and school experiences" (Shizha, 2012, p. 879). Learning and thinking in indigenous languages would enable students to connect to their home experiences and transmit, produce and advance their indigenous knowledge and culture. Arguably, all school subjects can make use of indigenous knowledge and expose students to indigenous intellectual traditions. Students' indigenous knowledge and discourses cannot be advanced in a foreign language. According to Ogunnaike (2018), societies with "different intellectual traditions have different ways of expressing their ideas and wisdom, different modes of study, different conceptions of knowledge and different epistemologies and different pedagogies" (p. 28). Using English as the medium of instruction produces students who are proficient in the western intellectual tradition, but not value their own (Ogunnaike, 2018).

To break away from the coloniality of knowledge is complicated and made difficult by political leadership, parents, and teachers' adherence to western epistemology and intellectual tradition. As those who shape and teach in the education system are products of western epistemology and intellectual traditions, they have a colonial mentality and outlook that they pass on to others (Shizha, 2012; Wa Thiong'o, 1994). Arguably, the Zimbabwe language policy fails to decolonize knowledge by centering indigenous knowledge through the use of indigenous languages as media of instruction and tools for mental liberation.

\section{Coloniality of Being: Self-pride and Self-assertion}

Language and being are inextricably intertwined (Williams, 2017). Language defines us and gives us a sense of belonging. Language as a medium of instruction is vital to the development of personal self-esteem, positive concept of oneself, high collective esteem, or attitude towards Journal of Contemporary Issues in Education, 2019, 14(2), pp. 2-15. doi: 10.20355/jcie29377 ISSN 1718-4770 
one's heritage, family and community (Morcom, 2017). Students' ethnic identity and being are preserved in their indigenous languages, not English (Mbah, 2012). Shizha's (2012) research on the effects of teaching science in the rural areas using English clearly reveals how the self-pride and self-assertion of students are being battered when they are forced to learn in a second language. Shizha writes that as a consequence of science instruction in English, "students are confused, frustrated, embarrassed, neglected, and ignored" (p. 880). According to Shizha (2012), a science teacher said the following in response to a student who had answered a science question in chiShona:

You should always try to answer in English. Are you going to use Shona in the examination? The examination has no Shona questions and you are not going to be asked to answer in Shona. Now go on in English. (p. 880)

Teachers' attitudes like these cultivate inferiority complexes in students and distance them from the indigenous languages that define their identity instead of giving them a sense of belonging and pride. The message conveyed to students is that their language is inferior and is not important, and in turn, their personal self-esteem and self-pride are damaged. They feel dehumanized. Arguably, they will feel that human beings are those who think and communicate in English. It will be very difficult if not impossible for students to be proud of their African humanity as long as English is the dominant language of instruction. Students will continue to be "colonial beings" who aspire to be something else other than themselves. The continued use of English as the medium of instruction encourages students to look at themselves "through the eyes of others, of measuring one's soul by the tape of a world that looks on in amused contempt and pity", and creates a "double-consciousness" (Du Bois, 1903, p. 5). It can be argued that instead of reclaiming the dignity and pride of the African, the language policy, as the colonial policy, promotes self-denigration.

\section{Conclusion and the Way Forward}

Thirty-nine years after independence, Zimbabwe's language policy is not fundamentally different from the colonial one. The language policy tinkered but did not radically change the colonial language policy and left colonial language policy fundamentals mostly intact (Nhongo, 2013; Shizha, 2012). Admittedly, in Zimbabwe, the development of language policy is a contested and highly politicized enterprise because it involves nation-building and cultural cohesion (Ndhlovu, 2008). This is complicated by the fact that the two liberation movements (ZANU and ZAPU) were mainly supported by people who spoke indigenous languages, namely Shona and Ndebele. Undeniably, the current language policy in Zimbabwe is steeped and anchored in coloniality. The language policy perpetuates the long-standing patterns of power that emerged from colonialism and is manifested in the use of English as the medium of instruction with devastating effects on indigenous ways of knowing and being. Like other researchers and policy analysts (Shizha, 2013, Shizha, 2012; Nhongo, 2013; Nkomo, 2008) we contend that the language policy only scratched the surface. It fails to vigorously confront the "coloniality of power, coloniality of being, and coloniality of knowledge" manifesting itself in the current language policy.

Journal of Contemporary Issues in Education, 2019, 14(2), pp. 2-15. 
In light of globalization, developing a relevant and suitable language policy will not be without its challenges. English is the language of information and technology (Shizha, 2012; Sukumane, 2000; Thondhlana, 2000). Displacing English as the medium of instruction and putting it at par with indigenous languages will entail taking the proverbial bull by its horns. In view of these challenges and problems we offer the following recommendations:

\section{Development of language policy}

To give the language policy some form of legitimacy, the top-down approach to language policy development must be replaced by a bottom-up mechanism that is all-inclusive, not exclusive. According to Ndhlovu (2008) and Mnkandla (2000) the Zimbabwe language policy was not a product of open and wide consultation. Ironically, the lack of a broad-consultative process is the hallmark of African governments' language policy formulation. Not all stakeholders (teachers, parents, students, civil society, policy analysts, researchers) were consulted because the policy was "more politically than educationally expedient" (Mnkandla, 2000, p. 84). It is imperative that all stakeholders should be involved in developing a people-oriented language policy that is rooted and grounded in people's experiences and aspirations. Ownership of the language policy is crucial for its successful implementation. More importantly, the language policy must be included in the constitution with its role in national development articulated without ambiguity. What inspires the language policy must be clearly articulated. For example, the South African language policy is clear on its - human rights-driven inspiration (Ndlovu, 2008). In the absence of articulation of its inspiration, some researchers have inferred that the policy performs "veiled political purposes of tribal balancing" (Ndhlovu, 2008, p. 62).

\section{Abolish language pyramid}

The language pyramid must be abolished to create a just and fair language landscape. Language is a fundamental human right and people should be able to use their language as a medium of instruction without hindrance or constraints (Mbah, 2012). A balanced relationship among languages is critical to give linguistic rights to speakers of other languages (iCamardons, 1997). Therefore, all indigenous languages should be used as media of instruction (Mufanechiya \& Mufanechiya, 2010). In grades one to three, not all minority indigenous languages are being used as medium of instruction, although the policy prescribes it. Muchenje et al. (2013) in their research found out that Chewa was not used as a medium instruction in grades one to three although this was the majority of the language of the students. In this regard, there is no equal treatment of indigenous languages (Hungwe, 2007). The English language should not be the only language of instruction, business, commerce, and administration. The use of other languages as media of instruction beyond grade three will reduce and minimize the dominance and supremacy of English. Zimbabwe may emulate the Tanzanian experience where English was "deinstitutionalized" and taught as a foreign language (Sukumane, 2000). Swahili is used as the medium of instruction in primary schools. Perhaps, this would de-mystify the supremacy and stranglehold of English as medium of instruction. According to Shizha (2012), teachers blame the Education Act and educational authorities for the use of English language as the sole medium of instruction. Examinations are in English and teachers are forced to use English as a medium of instruction to enhance student academic achievements. Teachers should propagate that no language is superior to the other or inferior to English. Politicians and educators must hold every Zimbabwean language "sanctimonious" and strive to promote it.

Journal of Contemporary Issues in Education, 2019, 14(2), pp. 2-15. doi: 10.20355/jcie29377 ISSN 1718-4770 


\section{Teacher education}

For teachers to promote the use of indigenous languages as media of instruction, the training of teachers needs re-visioning and transformation. Shizha (2012) argues that "pre-service training should be reformed to take into account the new education language policy...." (p. 883). Teacher education should expose teacher candidates to different intellectual traditions so that they acknowledge them not as mere religious training or informal education (Ogunnaike, 2018). Teachers in training must study at length the benefits of code-switching to tolerate it in classroom interactions. Code-switching allows teachers to use both indigenous languages and English in their teaching to enhance student understanding. Shizha (2012) recommends flexibility in the use of the medium of instruction to allow code-switching. Furthermore, professional development in the form of seminars and workshops should be intensified for practicing teachers.

\section{Resource mobilization}

The government, particularly the staff working in the Ministry of Education should demonstrate their commitment to transforming the colonial language policy. As it is, many observers and analysts posit that the government lacks both the will and capacity to change the colonial language policy (Mnkandla, 2000; Nhongo, 2013). The Zimbabwean government has not mobilized the much needed financial and material resources necessary to teach students in their indigenous languages beyond grade three (Mufanechiya \& Mufanechiya, 2010; Thondhlana, 2000). The government claims that there is no money to train teachers to teach using indigenous languages and to develop instructional materials for these languages. Perhaps the government needs to increase the education budget by cutting down on unnecessary expenditure or even reduce the number of ministries and cabinet posts.

A single language document would render the policy more forceful. The fact that there is no single language policy document speaks to the lack of determination by the government to radically change the colonial language policy (Hadebe, 1998). Zimbabwe is not the only African country whose language policy is not contained in a single document. Nigeria's language policy is not in one single document but in parts of other legal documents. It is incumbent upon the government to design and implement policies and strategies that will change the attitudes of teachers and the population to recognize the value and importance of mother tongues for learning and national development (Shizha, 2012). These implementation strategies must be time-specific and monitored. The "confusion" in the interpretation of the policy and its "half-hearted" implementation at the primary level is a serious indictment on the government's commitment to language policy change. Mufanechiya and Mufanechiya (2010) found that each school interpreted the policy differently. Some schools used English as medium of instruction from grade one, and others from grade four.

\section{Research and innovation}

Research on how indigenous languages may be used as media of instruction in all subjects must be intensified. Although the Presidential Commission on Education and Training recommended the use of indigenous languages in education and training, the recommendations of this commission have not been put into practice. There are a number of studies that have

Journal of Contemporary Issues in Education, 2019, 14(2), pp. 2-15. 
demonstrated the benefits of mother-tongue instruction. The Ife Six-Year project in Nigeria showed that indigenous languages are better media of instruction than a foreign language because teachers and students are in command of the learning (Bamgbose, 2005). The Zimbabwean government through the Ministry of Education should study how other countries have leveraged their languages for national development. It is my considered view that Zimbabwe cannot make progress with a colonial language. Zimbabwe has the potential to develop a radical language policy given its revolutionary traditions and values.

\section{References}

Bamgboșe, A. (2005). Mother-tongue education: Lesson from the Yoruba experience. In B. Brock-Utne, \& R. K. Hops (Eds.), Languages of instruction for African emancipation: Focus on postcolonial contexts and considerations. CT, SA: CASAS.

Bourdieu, P. (1991). Language and symbolic power. Cambridge, MA: Harvard University Press. Brock-Utne, B. (2005). Language-in-education policies and practices in Africa with a special focus on Tanzania and South Africa-Insights from research in progress. In International handbook on globalisation, education and policy research (pp. 549-565). Dordrecht: Springer.

De Lissovoy, N. (2014). Education and emancipation in the neoliberal era: Being, teaching, and power. New York, NY: Springer.

Du Bois, W. E. B. (1903/1994). The souls of the folk. Chicago, IL: A. C. McClurg.

Fanon, F. (1952/1967). Black skin, White masks. New York, NY: Routledge

Fanon, F. (1961/2004). The wretched of the earth. New York, NY: Grove Press.

Freire, P. (1972). Pedagogy of the oppressed. New York, NY: Herder.

Government of Zimbabwe (1982). Transitional National Development Plan 1982/83-1984/85. Harare, Zimbabwe: Government Printer.

Government of Zimbabwe (1987). Education Act. Harare, Zimbabwe: Government Printer.

Government of Zimbabwe (1999). Report of the Nziramasanga Commission of Inquiry into Education and Training. Harare, Zimbabwe: Government Printer.

Hadebe, S. (1998). Socio-linguistic issues and human factor development. In V. G. Chivaura, \& C. G. Mararike (Eds.), The human factor approach to development in Africa (pp. 121134). Harare: UZ Publications.

Hungwe, K. (2007). Language policy in Zimbabwean education: Historical antecedents and contemporary issues. Compare, 37(2), 135-149.

iCamardons, J. S. (1997). Planning multilingualism: The Catalan case. Sociolinguistics, 11, 4352.

Kadenge, M., \& Nkomo, D. (2011). Language policy, translation and language development in Zimbabwe. Southern African Linguistics and Applied Language Studies, 29(3), 259-274.

Lugard, L. F. J. (1922/1965). The dual mandate in British tropical Africa. Hamden, CT: Archon Books.

Makoni, S. B., Dube, B., \& Mashiri, P. (2006). Zimbabwe colonial and post-colonial language policy and planning practices. Current issues in language planning, 7(4), 377-414.

Maldonado-Valentín, M. (2016). An exploration of the effects of language policy in education in a contemporary Puerto Rican society. Education Policy Analysis Archives, 24(85), 1-24.

Journal of Contemporary Issues in Education, 2019, 14(2), pp. 2-15. 
Maldonado-Torres, N. (2007). On the coloniality of being: Contributions to the development of a concept. Cultural Studies, 21(2-3), 240-270.

Makuvaza, N. (2008). Conquest, colonial education and cultural uprootedness in Africa: The Role of Education for hunhu/ubuntu in de-rooting the African in Zimbabwe. Zimbabwe Journal of Educational Research, 20(3), 371-388.

Mavhunga, P. J. (2006). Africanizing the school curriculum: A case for Zimbabwe. Zimbabwe Journal of Educational Research, 20(1), 30-48.

Mbah, B. M. (2012). Language policy, mothertongue education and the role of the Nigerian language teacher in Nigerian language education. Language Policy, 3(10), 48-54.

Mignolo, W. (2011). The darker side of western modernity: Global futures, decolonial options. Durham, NC: Duke University Press.

Mignolo, W. (2012). Local histories/global designs: Coloniality, subaltern knowledges, and border thinking. Princetown, NJ: Princeton University Press.

Mnkandla, M. (2000). An investigation of the implementation of Zimbabwe's language policy in primary education. Zimbabwe Journal of Educational Research, 12(1), 75-99.

Morcom, L. A. (2017). Self-esteem and cultural identity in Aboriginal language immersion kindergarteners. Journal of Language, Identity \& Education, 16(6), 365-380.

Muchenje, F., Goronga, P., \& Bondai, B. (2013). Zimbabwe language policy in education and the 'silenced voices': A case study of Nyanja? Chewa speaking pupils from Porta and Kintyre primary schools in Zvimba, Zimbabwe. Academic Research International, 4(2), 500-511.

Mufanechiya, T., \& Mufanechiya, A. (2010). The use of English language as the medium of instruction in the Zimbabwean Junior Primary Schools. NJLC: Journal of Language \& Communication, 4(2), 115-127.

Ndlovu-Gatsheni, S. J. (2015). Decoloniality as the future of Africa. History Compass, 13(10), 485-496.

Mumpande, I. (2006). Silent voices: Indigenous languages in Zimbabwe: A report. Harare, Zimbabwe: Weaver Press.

Ndamba, G. T. (2008). Mother tongue usage in learning: An examination of language preferences in Zimbabwe. The Journal of Pan African Studies, 2(4), 171-188.

Ndhlovu, F. (2008). The conundrums of language policy and politics in South Africa and Zimbabwe. Australian Journal of Linguistics, 28(1), 59-80.

Nhongo, R. (2013). A national language policy for Zimbabwe in the twenty-first century: Myth or reality? Journal of Language Teaching and Research, 4(6), 1208-1215.

Nkomo, D. (2008). Language in education and language development in Zimbabwe. Southern African Linguistics and Applied Language Studies, 26(3), 351-362.

Ogunnaike, O. (2018). Of canons and cannons. The promise and perils of postcolonial education. Renovatio. The Journal of Zaytuna College, 2(2), 25-39.

Quijano, A. (2000). Coloniality of power and social classifications. Journal of World Systems, $6(2), 342-386$.

Shizha, E., \& Abdi, A. A. (2014). Introduction. In E. Shizha \& A.A. Abdi (Eds.), Indigenous discourses on knowledge and development in Africa (pp. 1-14). New York, NY: Routledge. 
Shizha, E. (2013). Reclaiming our indigenous voices: The problem with postcolonial SubSaharan African school curriculum. Journal of Indigenous Social Development, 2(1), 118.

Shizha, E. (2012). Reclaiming and re-visioning indigenous voices: The case of the language of instruction in science education in Zimbabwean primary schools. Literacy Information and Computer Education Journal (LICEJ), Special Issue, 1(1), 785-793.

Shizha, E. (2010). Rethinking and reconstituting indigenous knowledge and voices in the academy in Zimbabwe: A decolonization process. In Indigenous knowledge and learning in Asia/Pacific and Africa (pp. 115-129). Palgrave Macmillan, New York.

Sukumane, J. B. (2000). Issues in language policy and planning: The case of Namibia. Studies in the Linguistic Sciences, 30(2), 199-208.

Thondhlana, J. (2002). Using Indigenous languages for teaching and learning in Zimbabwe. In B. Burnaby, \& J. Reyhner (Eds.), Indigenous languages across the community (pp. 31-39). Flagstaff: Arizona. Retrieved from http://jan.ucc.nau.edu/jar/ILAC

Wa Thiong'o, N. (1994). Decolonising the mind: The politics of language in African literature. Nairobi, Kenya: East African Publishers.

Williams, D. (2017). Language and being: Heidegger's linguistics. New York, NY: Bloomsbury Publishing. 